\title{
Kapasitas Aparatur Pemerintah Desa Dalam Inovasi Upaya Penanggulangan dan Pencegahan Penyebaran Corona Virus Disease 2019 (Covid-19)
}

\author{
Oleh: \\ Sasmito Jati Utama. \\ Program Studi Ilmu Administrasi Publik \\ Universitas Hang Tuah Surabaya \\ Email: sasmito.jatiutama@hangtuah.ac.id
}

\begin{abstract}
A Demerintah pusat melalui Kementerian Desa, Pembangunan Daerah A Tertinggal dan Transmigrasi memberikan instruksi untuk pencegahan B 1 Covid-19 ditingkat desa melalui Surat Edaran Nomor 8 Tahun 2020 tentang Desa Tanggap Covid-19 dan Penegasan Padat Karya Tunai Desa. Adapun ruang lingkup Surat Edaran ini meliputi (1) Penegasan PKTD, (2) Desa Tanggap COVID-19; dan (3) Penjelasan perubahan APBDes.. Tulisan ini mengkaji mengenai kapasitas aparatur pemerintah desa dalam inovasi penanggulangan dan pencegahan penyebaran Corona Virus Disease 2019 (Covid-19) di wilayahnya, melalui studi literatur, yang berfokus pada kapasitas-kapasitas aparatur khususnya pemerintah desa dalam upaya pencegahan dan penanganan COVID-19 berdasarkan praktek terbaik di Indonesia. Kapasitas aparatur pemerintah desa yang diperlukan sebagai inovasi dalam upaya penanggulangan dan pencegahan penyebaran Corona Virus Disease 2019 (Covid-19) di wilayahnya dapat disimpulkan bahwa seorang kepala desa membutuhkan kapasitas responsif, kapasitas ekstraktif, kapasitas regulatif, kapasitas distributif dan kapasitas kolaboratif.
\end{abstract}

Kata Kunci: kapasitas, aparatur, ekstraktif, responsive, Covid-19

\section{$T$} The central government through the Ministry of Villages, Disadvantaged Areas and Transmigration provides instructions for the prevention of Covid-19 at the village level through Circular Number 8 of 2020 concerning Covid-19 Response Villages and Affirmation of Village Cash Work. The scope of this Circular Letter includes (1) Confirmation of PKTD, (2) COVID-19 Response Villages; and (3) Explanation of changes to APBDes. This paper examines the capacity of village government officials in innovation to control and prevent the spread of Corona Virus prevention and response to COVID-19 based on best practice in Indonesia. The capacity of the village government apparatus that is needed as an innovation in efforts to control and prevent the spread of Corona Virus Disease 2019 (Covid-19) in their area can be concluded that a village head needs responsive capacity, extractive capacity, regulatory capacity, distributive capacity and collaborative capacity.

Keywords: capacity, apparatus, extractive, responsive, Covid-19

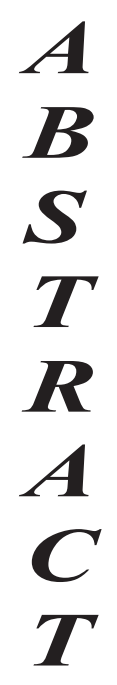

\section{A. PENDAHULAN.}

Perkembangan penyebaran kasus Covid-19 di Indonesia tidak hanya terjadi di wilayah perkotaan, tetapi juga hingga ke pedesaan. Hal mana Pemerintahan Desa merupakan bagian dari sub sistem Pemerintahan Daerah yang langsung bersentuhan dengan masyarakat. 
Sehingga dalam konteks menghadapi pandemi COVID-19 di daerah selain menjadi tanggung jawab kepala daerah, seharusnya kepala desa mengambil peran dan tanggung jawab yang sama dalam hal menghadapi COVID-19 di lingkup wilayahnya, dan hakikinya menjadi garda terdepan pemerintahannya dengan peran yang lebih dioptimalkan. Berdasarkan Undang-undang Nomor 6 Tahun 2014 Tentang Desa, pasal 4 hurup (g) yaitu, salah satu tujuan pengaturan Desa adalah meningkatkan ketahanan sosial budaya masyarakat desa guna mewujudkan masyarakat desa yang mampu memelihara kesatuan sosial sebagai bagian dari ketahanan nasional. Sehingga desa dapat dioptimalkan untuk membuat ketahanan sosial baik dari segi pencegahan penyebaran Covid-19 maupun ketahanan ekonomi masyarakat desa dalam menghadapi pandemi ini.

Beragam kebijakan baik dari kementerian Dalam Negeri, Kementerian Desa, Pembangunan Daerah Tertinggal dan Transmigrasi (Kemendes PDTT), Kementerian Keuangan, Komisi Pemberantasan Korupsi hingga Lembaga Kebijakan Pengadaan Barang dan Jasa Pemerintah turut 'mengawal' dan mendukung tata kelola pemerintah desa dalam upaya pencegahan penyebaran Covid-19 di wilayah pedesaan. Salah satunya, kebijakan Kementerian Desa, Pembangunan Daerah Tertinggal dan Transmigrasi (Kemendes PDTT) yang memberikan arahan berdasarkan Pasal 5 Peraturan Menteri Kementerian Desa, Pembangunan Daerah Tertinggal dan Transmigrasi (Kemendes PDTT) Nomor 11 Tahun 2019 tentang Prioritas Penggunaan Dana Desa Tahun 2020 adalah bidang Pembangunan Desa dan Pemberdayaan Masyarakat Desa, meliputi: a. Peningkatan kualitas hidup; b. Peningkatan kesejahteraan; c. Penanggulangan kemiskinan; dan d. Peningkatan pelayanan publik. Kegiatan peningkatan pelayanan publik diutamakan untuk membiayai pelaksanaan program bidang kesehatan, pendidikan dan sosial, sedangkan peningkatan kualitas hidup masyarakat desa diutamakan untuk membiayai pelaksanaan program dan kegiatan di bidang pelayanan sosial dasar yang berdampak langsung pada meningkatnya kualitas hidup masyarakat seperti pengadaan, pembangunan, pengembangan, serta pemeliharaan sarana dan prasarana lingkungan alam untuk: 1) kesiapsiagaan menghadapi bencana alam; 2) penanganan bencana alam; Desa-desa dapat melakukan penyesuaian program penanganan dan pencegahan COVID-19 sesuai dengan situasi yang terjadi. Bagi desa-desa yang terdampak, antisipasi protokolnya pemerintah desa harus berpedoman instruksi pelaksanan Gugus Tugas Penanganan COVID-19.

Lebih lanjut, terkait dengan prioritas penggunaan dana desa untuk memperkuat sendi-sendi ekonomi melalui Padat Karya Tunai Desa (PKTD), dan penguatan kesehatan masyarakat melalui upaya pencegahan dan penanganan COVID-19. Pemerintah pusat melalui Kementerian Desa, Pembangunan Daerah Tertinggal dan Transmigrasi (Kemendes PDTT) memberikan instruksi untuk pencegahan Covid-19 ditingkat desa melalui Surat Edaran Nomor 8 Tahun 2020 tentang Desa Tanggap Covid-19 dan Penegasan Padat Karya Tunai Desa. Adapun ruang lingkup Surat Edaran ini 
meliputi (1) Penegasan PKTD, (2) Desa Tanggap COVID-19; dan (3) Penjelasan perubahan APBDes.

Kebijakan-kebijakan yang dijalankan pemerintah desa dalam upaya pencegahan penyebaran Covid-19 menempatkan fungsi aparatur pemerintah desa yang sangat krusial penyelenggaraannya. Sehubungan dengan hal tersebut, tulisan ini mencoba untuk menelaah peran aparatur pemerintah desa khsusunya kepala desa dalam mendukung upaya pencegahan penyebaran Covid-19 di pedesaan. Sehingga pertanyaan yang muncul adalah "Bagaimana Kapasitas Aparatur Pemerintah Desa Dalam Inovasi Penanggulangan dan Pencegahan Penyebaran Corona Virus Disease 2019 (Covid-19) di wilayahnya?".

\section{B. METODE}

Penelitian ini dilaksanakan dengan metode studi literatur, yang berfokus pada kapasitaskapasitas aparatur khususnya pemerintah desa dalam upaya pencegahan dan penanganan COVID19 berdasarkan praktek terbaik di Indonesia. Adapun focus yang dibahas dalam tulisan ini meliputi:

a. Kapasitas regulasi (mengatur), yang berupa kemampuan pemerintah dalam hal ini pemerintah desa untuk mengatur kehidupan pemerintah desa beserta isinya (wilayah, kekayaan dan penduduk) dengan peraturan, berdasarkan kebutuhan dan aspirasi masyarakat setempat.

b. Kapasitas ekstraktif, kemampuan mengumpulkan, mengarahkan dan mengoptimalkan aset-aset desa untuk menopang kebutuhan (kepentingan) pemerintah dan warga masyarakat.

c. Kapasitas distributif, yaitu kemampuan pemerintah dalam hal ini pemerintah desa untuk membagi sumber daya daerah secara seimbang dan merata sesuai dengan prioritas kebutuhan masyarakat.

d. Kapasitas responsif, kemampuan untuk peka atau memiliki daya tanggap terhadap aspirasi atau kebutuhan warga masyarakat untuk dijadukan sebagai basis dalam perencanaan kebijakan pembangunan di desa.

e. Kapasitas jaringan dan kerja sama, kemampuan pemerintah dan warga masyarakat mengembangkan jaringan kerjasama dengan pihak-pihak luar dalam rangka mendukung kapasitas efektif.

\section{HASIL DAN PEMBAHASAN}

\section{a. Kapasitas Responsif}

Kapasitas responsif kemampuan untuk peka atau memiliki daya tanggap terhadap aspirasi masyarakat sebagai dasar perencanaan dalam upaya penanggulangan dan pencegahan penyebaran Corona Virus Disease 2019 (Covid-19) di wilayahnya. Sehingga hal ini dapat mewujudkan sebagai Desa Tanggap Covid-19. Hal ini ditunjukkan dengan bentuk tindakan sebelum ada kejadian pasien positif di wilayahnya. Tindakan yang bersifat responsif ini dapat dilakukan ketika kejadian awal dinyatakan awal pasien positif pada lingkup nasional. Semakin tindakan respon berdekatan dengan 
waktu awal ada pasien positif pada lingkup nasional maka akan semakin baik dalam menjalankan langkah-langkah antisipatif lainnya.

Adapun beberapa bentuk kegiatan sebagai kapasitas responsive ini, Kepala Desa selaku aparatur pemerintah desa dapat bertindak untuk :

a). Membentuk sistem komunikasi warga, bisa melalui whatsapp, sms, atau aplikasi komunikasi lainnya

b). Membuat peraturan yang harus dilaksanakan untuk keselamatan warga, terutama terkait: larangan berkumpul, larangan membuat acara di wilayah tersebut, larangan lain terkait keamanan dan keselamatan warga secara fisik dan sosial/ termasuk datangnya pendatang/pemudik serta perlunya dengan disertai sanksi yang disetujui bersama oleh pengurus RTdan warga.

c). Membuat komunikasi yang cepat apabila terjadi sebuah insiden apapun di wilayahnya.

d). Menunjuk warga atau meminta kesukarelaan warga untuk menjadi penanggung jawab bidang tertentu. Adapun bidang yang diperlukan: bidang komunikasi, kesehatan, operasi, logistik, dan keamanan.

Dalam konteks penanggulangan dan pencegahan penyebaran Covid-19 pada kapasitas responsif seorang kepala desa dapat bertindak dalam 2 (dua) katagori besar. Katagori pertama, berupa mengoptimalkan kemampuan yang yang menjadi kewenangannya melalui aksi yang sifatnya support (pemberian dukungan). Katagori kedua, adalah dalam wujud daya tanggap terhadap aspirasi masyarakat melalui pengoptimalan peran berhubungan dengan kewenangan diluar dirinya (pelaporan dan koordinasi). Katagori ini aktifitas yang dilakukan erat kaitannya dengan pihak-pihak luar pemerintahan desa. Adapun respon awal dari yang mampu mewadahi kedua katagori tersebut adalah mengadakan rapat/musyawarah dengan tujuan adanya pengorganisasian. Pengorganisasian yang dimaksud adalah mengorganisasikan terhadap aksi yang sifatnya support (pemberian dukungan) sesuai kewenangannya dan mengorganisasikan terhadap aksi yang sifatnya pelaporan dan koordinasi terhadap hal-hal diluar kewenangan desa. Hal ini secara pengorganisasian pada level puncak dapat dibentuk pusat pengendali yang terdiri dari pimpinan (coordinator) serta kesekretariatan dan kebendaharaan.

Pada katagori pertama, kegiatan yang dilaksanakan adalah :

a). Mendukung dan membentuk relawan hal mana relawan ini terbagi dalam :

- Profesional terdiri dari medis dan non medis

- Non profesional terdiri dari yang menangani teknsi distribusi dan dapur umum

b). Mendukung terbentuknya bantuan/donasi. Bentuk donasi dapat berupa barang dan uang. Dalam bentuk barang, donasi dipilah yang termasuk sembako dan non sembako. Sedangkan donasi uang, dapat berupa tunai dan non tunai. 
Pada katagori pertama dibentuk satuan tugas-satuan tugas (satgas-Covid-19). Selanjutnya pada tataran operasional dapat dibentuk satgas-satgas, diantaranya satgas relawan profesional, satgas non professional, satgas pengadaan, produksi dan distribusi (menangani donasi barang), dan satgas pembiayaan (menangani donasi uang). ang dapat tergabung dalam dapat menjadi pilar tumbuh kembangnya pemberdayaan masyarakat dalam konteks pencegahan penyebaran Covid-19. Aspirasi utama dalam situasi pandemic ini adalah rasa aman dan lingkungan yang sehat. Oleh karena itu langkah antisipatif dapat dilakukan oleh kepala desa.

Selanjutnya, pada katagori kedua, yang berhubungan dengan peran pelaporan dan koordinasi, maka dapat dilaksanakan kegiatan pendayagunaan data dan informasi. Kegiatan ini adalah pendataan dan analisa sehingga diketahui warga masyakat diwilayah dalam katagori terdampak dan tidak terdampak. Hasil analisa terhadap warga yang termasuk katagori terdampak ini, selanjutnya dapat dipilah menjadi 2 kelompok besar yaitu :

a). Terdampak secara klinis. Pada kelompok terdampak secara klinis terbagi menjadi 3 tingkat yaitu resiko tinggi, sedang dan rendah. Perbedaan tingkat resiko berimplikasi pada penanganan tindak lanjutnya yaitu Resiko tinggi dengan penanganan asistensi klinis, Resiko sedang dengan monitoring klinis dan Resiko rendah dengan edukasi klinis.

b). Terdampak secara sosial. Eksistensi wabah berdampak pada perubahan pola hidup untuk lebih sehat dan protektif. Hal ini dialami oleh seluruh warga desa dengan memperkenalkan protokolprotokol kesehatan. Protokol tersebut diharapkan tersosialisasi sebagai sebuah pranata sosial warga masyarakat. Selain itu dilakukan kegiatan dekontaminasi/penyemprotan disinfektan berkala untuk pencegahan penyebaran wabah pada area umum, seperti di sekolah/PAUD, pasar, tempat-tempat ibadah, balai desa, polindes, poskesdes, dan lain-lain.

c). Terdampak secara ekonomi. Hal mana kegiatan pembatasan sosial menyebabkan kegiatan ekonomi warga turut terdampak. Oleh karena itu terdapat kerentanan pada warga masyarakat dengan semakin menurunnya pendapatan. Oleh karena itu pendataan yang akurat bagi warga terdapak ekonomi dibutuhkan untuk didukung dengan program-program bantuan diantaranya Program Padat Karya Desa (PKTD) dan Jaring Pengaman Sosial (JPS).

Pengorganisasian pada katagori kedua ini, dapat dibentuk satuan tugas data dan informasi, satgas mitigasi sosial dan satgas mitigasi ekonomi. Lebih lanjut visualisasi wujud kapasitas responsif ini dapat dilihat pada gambar berikut. 


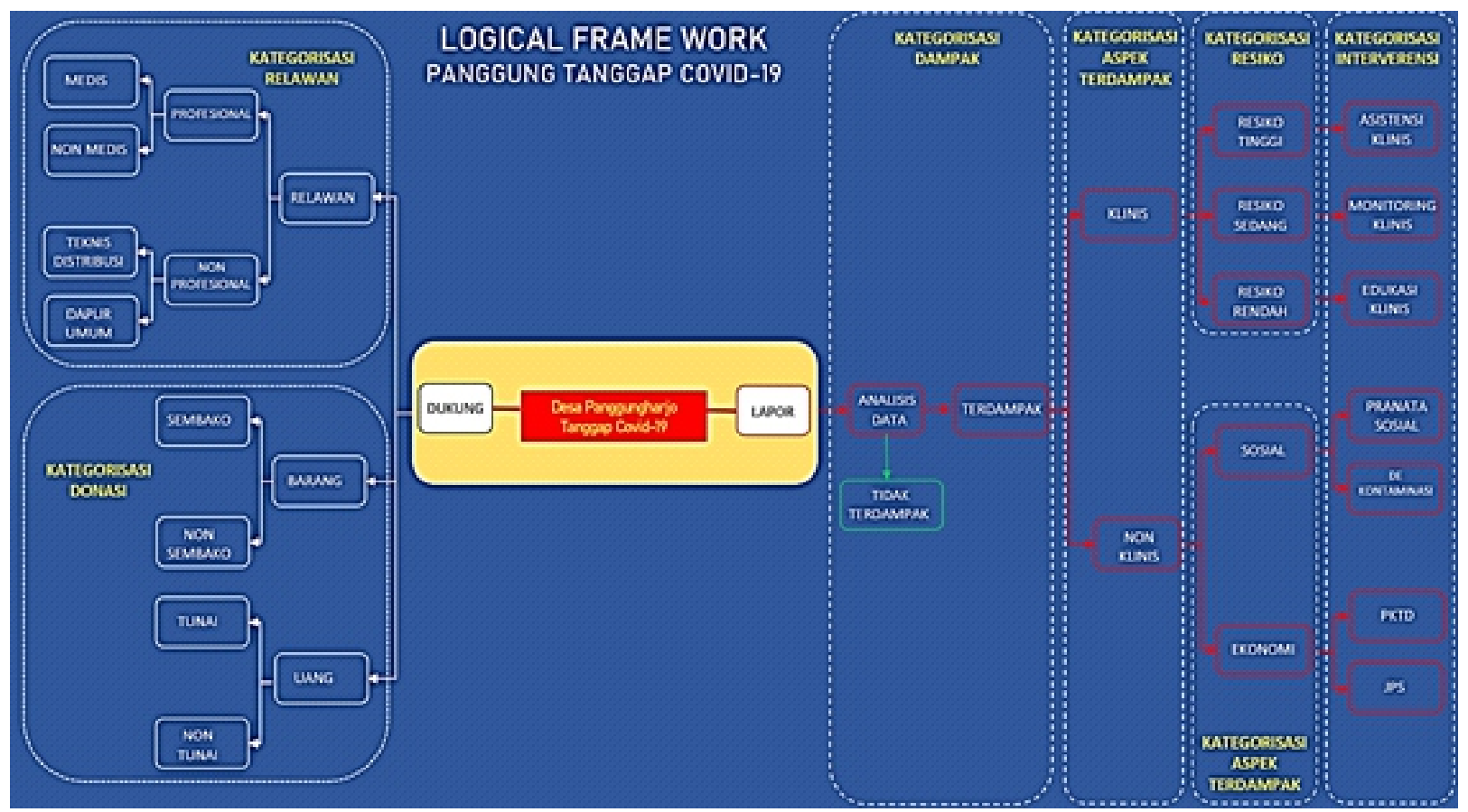

Sumber : diolah dari presentasi Kades Panggungharjo, Bantul DIY pada Workshop Online Jitupasna BPBD DIY tanggal 16 Juni 2020.

Gambar 1. Ilustrasi Kerangka Kerja Desa Panggungharjo Tanggap Covid-19

Eksistensi kapasitas responsive sebagaimana contoh dilaksanakan oleh Desa Panggungharjo Kabupaten Bantul apabila ditinjau dari secara subatansinya mampu mendorong pemberdayaan masyarakat dalam penanggulangan dan pencegahan penyebaran Covid-19 di wilayahnya dan mewujudkan sebagai Desa Tanggap Covid-19. Adapun aktifitas kunci sebagai aktifitas yang responsif yang mendukung pemberdayaan ini diantaranya :

\section{a. Pendataan Kesehatan Warga di RT/RW/Desa}

- Mendata kesehatan seluruh warga menggunakan formulir pendataan warga termasuk warga yang berisiko tinggi

- Mendata warga yang keluar dan masuk di wilayahnya

- Menghimbau warga untuk menginformasikan jika ada orang asing atau warga yang datang dari wilayah yang sudah terjangkit COVID-19 yang masuk ke wilayahnya.

b. Mencari kemungkinan faktor penyebab penularan COVID-19 dan potensi wilayah

- Faktor Perilaku : tidak melakukan PHBS/CTPS

- Non Perilaku : lingkungan

- Mendata potensi : SDM, Dana, Sarana Prasarana

c. Musyawarah Masyarakat RT/RW/Desa

- Sosialisasi hasil pendataan dan kemungkinan faktor penyebab penularan

- Sosialisasi program pemerintah dalam pencegahan COVID-19

- Menyepakati kegiatan melalui pemberdayaan masyarakat

d. Menyusun Rencana Kegiatan di Masyarakat

- Sampaikan informasi tentang COVID-19 (penyebab, penularan, pencegahan. 
- Edukasi tentang cara-cara pencegahan COVID-19 (etika batuk, cara cuci tangan pakai sabun, cara menggunakan masker)

- Sarana edukasi: pengeras suara/toa, saluran komunikasi elektronik (group whats app, dll)

- Jadwal pelaksanaan, sasaran kegiatan, rencana anggaran dan penanggung jawab sesuai formulir Rencana Kegiatan.

\section{e. Pelaksanaan Kegiatan}

Dilaksanakan sesuai jadwal yang telah direncanakan bersama. Kegiatan dicatat dan dilaporkan mengguna- kan format Laporan Kegiatan.

\section{f. Keberlangsungan Kegiatan}

Dilakukan oleh masyarakat bersama dengan pengurus RT/RW/Desa dan pendamping teknis (puskesmas), untuk menjamin kesinambungan pemberdayaan masyarakat.

\section{b. Kapasitas Ekstraktif}

Kapasitas ekstraktif merupakan kemampuan mengumpulkan, mengerahkan dan mengoptimalkan aset desa untuk menopang kepentingan pemerintah dan masyarakat desa serta kemampuan mengkonsolidasikan berbagai aktor di desa. Sehubungan dengan hal tersebut kemampuan mengumpulkan, mengerahkan dan mengoptimalkan juga melekat dalam katagori responsive. Hal ini dapat dilihat dari terbentuknya relawan baik profesional terdiri dari medis dan non profesional. Selain itu kemampuan mengumpulkan sumber daya dapat dilihat dari kemampuannya untuk mendorong adanya bantuan/donasi baik barang maupun uang uang.

Kemampuan ekstraktif dalam mengkonsolidasikan berbagai aktor di desa dalam upaya penanggulangan dan pencegahan penyebaran Corona Virus Disease 2019 (Covid-19) di wilayahnya ini juga dapat dilihat dari adanya distriburi peran dari aktor-aktor yang terlibat. Adapun distribusi peran tersebut meliputi :

\section{a). Kepala Desa/Ketua RT/RW}

- .Menyampaikan informasi tentang COVID-19 kepada warga

- .Mengedukasi warga:

- Upaya pencegahan COVID-19

- Isolasi mandiri di rumah

- $\quad$ Agar tidak memberi stigma buruk kepada ODP, PDP atau positifCOVID-19

- Memfasilitasi dan mendorong keaktifan perangkat RT/RW/Desa, Toga/Toma, Kader, Bhabinkambtibmas, relawan desa lawan COVID-19 dan kelompok potensial warga lainnya dalam pencegahan penu laran COVID-19

- .Mendorong partisipasi warga untuk:

- Menjaga kebersihan diri, kebersihan rumah dan lingkungan

- Melakukan pembatasan kontak fisik

- Tidak berkerumun/berkumpul

- Tetap berada di rumah

- . Bekerjasama dengan Puskesmas setempat

- .Menyediakan sarana CTPS 
- Membuat alur pengorganisasian pemenuhan logistik bagi warga yang melakukan isolasi mandiri di rumah

- Menggalang donasi untuk mendukung keluarga yang melakukan isolasi mandiri

- Melaporkan kepada Lurah/Kades terkait hal-hal yang dianggap berpotensi meningkatkan penularan COVID-19

- Melakukan pemantauan mobilitas warga yang berasal dari daerah terkena COVID-19

- Membantu warga yang kurang mampu/sakit/lansia yang tidak memiliki keluarga

- Memastikan warga di wilayahnya mematuhi aturan yang telah disepakati Bersama.

b). Tokoh Agama/Tokoh Masyarakat

- Menyampaikan informasi pencegahan COVID-19 kepada warga melalui pendekatan budaya/agama

- Tokoh agama memasukkan materi COVID-19 dalam ceramah/tausiah yang diberikan

- Mengajak warga berpartisipasi dalam upaya pencegahan COVID-19

- Membantu Ketua RT/RW/Kepala Dusun dalam mengedukasi warga:

- Agar tidak memberi stigma buruk kepada ODP, PDP atau positifCOVID-19

- Bahwa jenazah warga positifCOVID-19 yang pulang dari RS sudah sesuai dengan SOP dan masyarakat tidak perlu khawatir.

c). Bhabinkamtibmas:

- Menyampaikan informasi pencegahan COVID-19 kepada warga

- Membantu penegakan disiplin masyarakat dalam melakukan:

- Social/physical distancing

- Tidak berkerumun

- Pembatasan jam buka/tutup kedai

- Tetap berada di rumah

- Melakukan siskamling atau pemantauan lingkungan secara rutin dan terjadwal

- Membantu melakukan pengamanan wilayah jika ditemukan ada kasus positif di lingkungan

d). Kader Kesehatan:

- Menyampaikan informasi pencegahan COVID-19 kepada warga sekitar

- Mendorong partisipasi warga untuk:

- Menjaga kebersihan diri, kebersihan rumah dan lingkungannya

- Melaksanakan pembatasan kontak fisik

- Membantu Ketua RT/RW/Kepala Desa dalam menyediakan makanan dan pemenuhan kebutuhan logistik bagi warga yang melakukan isolasi mandiri di rumah

- Bekerjasama dengan Puskemas membahas jadwal dan kegiatan di masyarakat seperti Posyandu atau lainnya, untuk sementara waktu ditunda dulu atau tetap dilaksanakan dengan menerapkan social dan physical distancing

e). Puskesmas:

- .Membantu Ketua RT/RW/Kepala Desa menganalisa data kesehatan warga.

- .Bekerjasama dengan Ketua RT/RW/Kepala Desa dalam melakukan pelacakan kasus yang ada di wilayah kerjanya

- .Memberi masukan kepada Ketua RT/RW/Kepala Desa dalam upaya memberikan edukasi kepada warga terkait COVID-19, Perilaku Hidup Bersih Sehat (PHBS) dan Gerakan Masyarakat Hidup Sehat (GERMAS) 
- Bekerjasama dengan kader membahas jadwal dan kegiatan di Posyandu atau lainnya, untuk sementara waktu ditunda dulu atau tetap menerapkan social dan physical distancing

- Memberikan layanan kesehatan yang dibutuhkan warga sesuai dengan ketentuan (seperti menggunakan APD saat pelayanan, dsb)

- .Melakukan pencatatan dan pelaporan secara rutin kepada Dinas Kesehatan Kab/Kota.

\section{f). Posyandu:}

.Pelaksanaan kegiatan dibahas antara petugas Puskesmas dan kader

.Kegiatan dapat dihentikan sementara atau jika tetap dilaksanakan, untuk memperhatikan hal-hal berikut:

- Mengatur jarak meja minimal 1 meter

- Menghimbau orang tua bayi dan balita membawa kain atau sarung sendiri untuk penimbangan atau bayi ditimbang bersama orang tua

- Mengatur masuknya pengunjung ke area pelayanan sehingga tidak banyak orang (maksimal 10 orang di area pelayanan, termasuk petugas)

- Menyediakan sarana cuci tangan pakai sabun dengan air mengalir di Posyandu

- Anak yang sudah diimunisasi diminta menunggu di sekitar (di luar) area pelayanan minimal 30 menit, di tempat terbuka, sebelum pulang (sesuai prinsip safety injection)

- Kader yang sakit agar tidak bertugas saat pelayanan

- Petugas dan kader memakai alat pelindung diri (APD).

\section{c. Kapasitas Regulatif}

Kapasitas regulasi (mengatur), yang berupa kemampuan mengatur sesuai kewenangannya dalam rangka dalam upaya penanggulangan dan pencegahan penyebaran Corona Virus Disease 2019 (Covid-19) di wilayahnya. Dalam rangka mewujudkan Desa Tanggap Covid-19, maka dibutuhkan adanya kemampuan mengatur yang berhubungan dengan pengaturan-pengaturan baik berupa pencegahan dan penanggulangan.

Dalam kapasitas regulative ini seorang kepala desa hendaknya membuat peraturan yang dapat ditindak lanjuti pada tingkat yang lebih kecil. Adapun beberapa peraturan yang perlu dibuat meliputi :

a). Wajib lapor RT bila ada pendatang yang menginap di rumah warga

b). Wajib lapor RT bila ada warga yang menjadi ODP atau PDP

c). Wajib lapor RT bila ada kematian di wilayah

d). Melarang acara sosial yang menyebabkan orang berkumpul

e). Melarang warga berkumpul di luar rumah atau di rumah selain rumahnya lebih dari 3 orang

f). Pemberlakuan jam malam apabila diperlukan Tanggap darurat bila terjadi wabah COVID19 di wilayah (karantina, isolasi, dll).

Sehubungan dengan kapasitas regulasi, maka diketahui terdapat beragam peraturan perundangan yang berhubungan dengan pemerintah desa dalam upaya penanggulangan dan pencegahan penyebaran Covid-19 di wilayahnya. 
Kebijakan Kemendagri, (Kemendes PDTT), Kementerian Keuangan, KPK hingga Lembaga Kebijakan Pengadaan Barang dan Jasa Pemerintah turut 'mengawal' dan mendukung tata kelola pemerintah desa dalam upaya pencegahan penyebaran Covid-19 di wilayah pedesaan. Hal utamanya adalah Surat Edaran Nomor 8 Tahun 2020 tentang Desa Tanggap Covid-19 dan Penegasan Padat Karya Tunai Desa. Adapun ruang lingkup Surat Edaran ini meliputi (1) Penegasan PKTD, (2) Desa Tanggap COVID-19; dan (3) Penjelasan perubahan APBDes.

\section{d. Kapasitas Distributif}

Kapasitas distributif, yaitu kemampuan dalam membagi sumber daya secara seimbang dan merata sesuai dengan prioritas kebutuhan masyarakat dan sesuai kewenangannya dalam rangka dalam upaya penanggulangan dan pencegahan penyebaran Corona Virus Disease 2019 (Covid-19) di wilayahnya. Dalam hal distribusi sumber daya ini maka erat kaitannya dengan kemampuan kepala desa mampu untuk mendistribusikan sumber daya khususnya terhadap warga yang terdampak secara klinis. Pada kelompok terdampak secara klinis (resiko tinggi, sedang dan rendah) maupun warga masyarakat di wilayahnya yang terdampak secara ekonomi.

Pada warga terdampak klinis ini terjadi dari situasi individu warga dalam katagori Orang Tanpa Gejala (OTG), Orang Dalam Pemantauan (ODP), dan Pasien Dalam Pengawasan (PDP). Katagori PDP Memiliki riwayat kontak dengan pasien COVID-19 maupun tinggal di wilayah dengan transmisi local. PDP sering mengalami demam $>38^{\circ} \mathrm{C}$, sesak napas batuk, pilek/sakit tenggorokan. Warga dengan status Orang Dalam Pemantauan (ODP) dan Pasien Dalam Pengawasan (PDP) yang ditetapkan oleh Rumah Sakit/Puskesmas harus mengisolasi mandiri dengan tetap tinggal di rumah. Oleh karena itu sehubungan dengan warga yang terdampak klinis ini kepala desa dapat berperan dalam kapasitasnya dengan beberapa kegiatan berikut.

\section{a). Melakukan musyawarah untuk:}

- Mengupayakan sumber daya untuk mendukung warga yang melakukan isolasi mandiri/ karantina rumah

- Menunjuk relawan desa lawan COVID-19 yang berasal dari perwakilan warga/kader untuk menyiapkan makanan dan kebutuhan personal hygiene untuk warga yang melakukan isolasi mandiri/karantina rumah

- Menunjuk perwakilan masyarakat untuk membantu mendistribusikan makanan dan logistik lain yang telah disiapkan.

b). Melaporkan kondisi warga ke Puskesmas

c). Mengingatkan warga yang melakukan isolasi untuk melakukan pemeriksaan kesehatan seperti mengukur suhu tubuh dan gejala lain serta pemeriksaan lanjutan.

Lebih lanjut kapasitas distribusi terhadap warga yang terdampak secara ekonomi. Oleh karena itu aspek pendataan yang akurat demikian penting bagi warga terdampak ekonomi untuk didukungengan program-program bantuan diantaranya Program Padat Karya Desa (PKTD) dan Jaring Pengaman Sosial(JPS). 
Sehubungan dengan peran distribusi ini, maka peran relawan khusunya bidang logistic demikian penting. Adapun tugas bidang logistik ini adalah :

- Mengatur cara penyediaan logistik dasar untuk warga ODP atau PDP yang dikarantina, termasuk obat-obatan dan alat kebersihan.

- Bila diperlukan, menggalang upaya kebun desa untuk menjaga pasokan makanan.

- Mengumpulkan semua nomor telepon penjual sembako yang melayani pesan antar.

- .Melakukan pendataan alat transportasi untuk evakuasi (ambulance terdekat, pengendara online, termasuk warga sendiri yang bersedia.

- Membentuk lumbung desa untuk menyimpan cadangan logistik bagi warga, berupa sembako, makanan kalengan dan alat kebersihan.

- Mendata warga yang mempunyai usaha pembuatan makanan agar bisa disebarluaskan kepada warga yang lain.

- Memastikan semua warga tidak kekurangan makanan.

\section{e. Kapasitas Kolaboratif}

Kapasitas kolaboratif, yaitu kemampuan kepala desa dan warga desa dalam rangka membangun jejaring kerjasama dengan pihak luar untuk mendukung kapasitas ekstraktif dari upaya pencegahan dan penanggulangan penyebaran Covid-19 di wilayahnya. Secara ekstraktif mengoptimalkan aset desa dengan membangun jejaring adalah tantangan yang memerlukan inovasi atau ide kreatif yang mudah untuk dioperasikan. Sebagai salah satu upaya mengoptimalkan aset desa salah satunya mengoptimalkan pasar desa. Dalam kapasitas kolaborasi, maka keberadaan teknologi mendukung inovasi dalam mengoptimalkan pasar desa yang yang dimiliki dengan semangat kolaborasi. Sebagai ilustrasi hadirnya Pasardesa.id menjadi sebuah upaya dari Pemerintah Desa (Pemdes) Panggungharjo Bantul DIY dalam menangani dampak persebaran Covid-19, terutama dalam aspek non-klinis (ekonomi). Sejak diresmikannya platform digital Pasardesa.id oleh Menteri Pembangunan Daerah Tertinggal dan Transmigrasi. Pasardesa.id adalah platform pasar milik desa untuk mengatasi kebutuhan konsumsi warga. Berawal dari upaya tanggap darurat dampak non-klinis (ekonomi) dari serangan Covid-19, Pasardesa.id menjadi solusi yang menghidupkan kembali kearifan lokal (karangkitri) untuk memenuhi kebutuhan pangan (konsumsi) warga di saat bencana. Berkat ini pula desa bertahan di saat bencana. Pasardesa.id menjadi bukti bahwa desa mampu berdaya mengatasi masalahnya sendiri. Pasardesa.id menjadi intermediary actor antara penjual dan pembeli, antara barang-barang bahan pokok yang tertahan di toko atau warung akibat wabah Covid-19. Sudah menjadi kewajiban kehadiran negara untuk menjadi fasilitator terhadap warga negaranya, melalui Pasardesa.id inilah langkah konkrit Pemdes Panggungharjo memfasilitasi warga desanya. Hadirnya platform pasardesa.id ini adalah upaya kita untuk menjembatani antara barang-barang persediaaan yang sementara kini tertahan di toko atau warung yang ada di Desa Panggungharjo. 

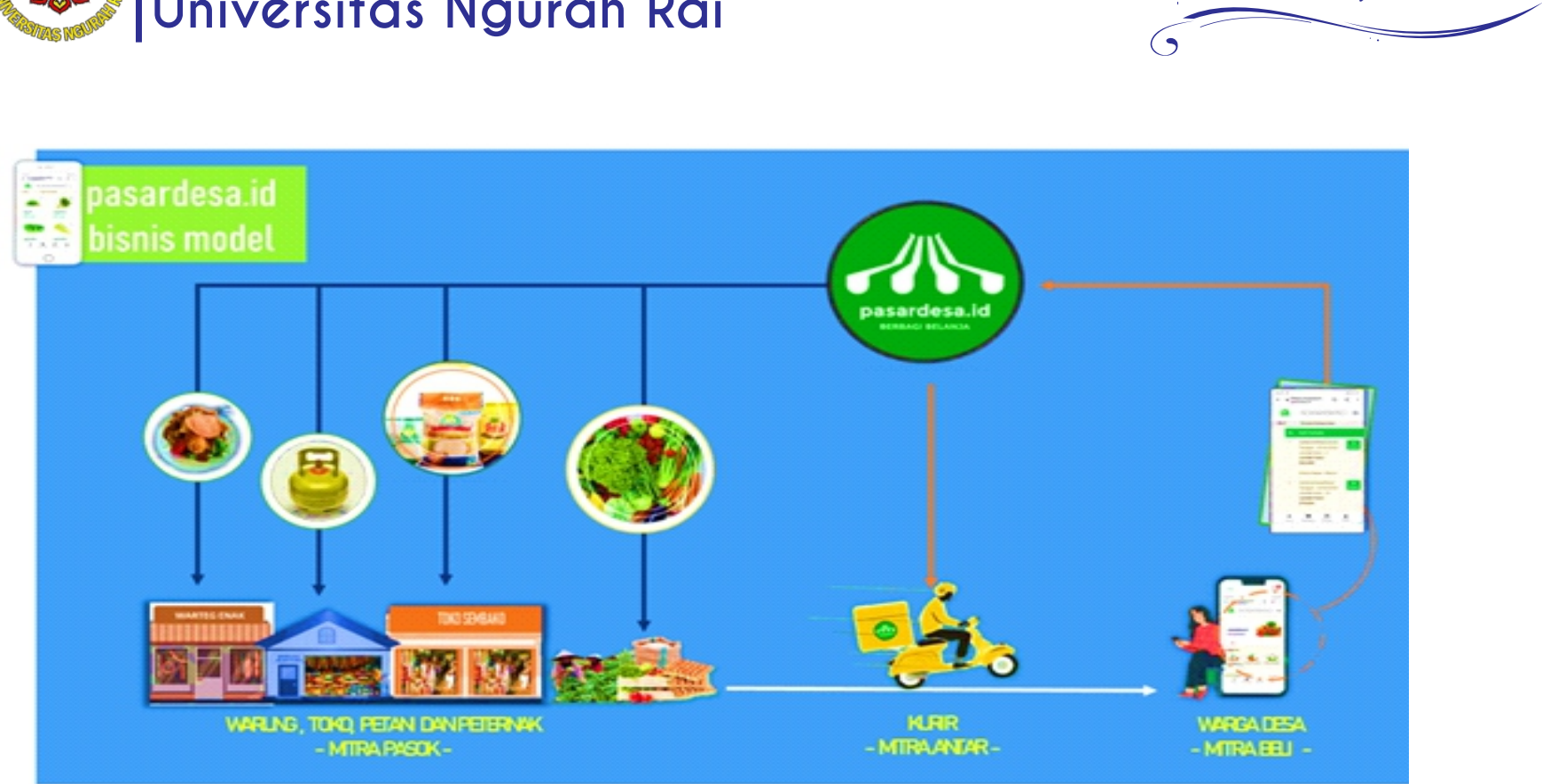

Gambar 2. Ilustrasi Model Bisnis Pasardesa.id

Berdasar informasi Pemerintah Kecamatan Sewon Bantul, PasarDesa.id Desa Panggungharjo berhasil meraih penjualan yang luar biasa. Capaian 100,69 juta rupiah besaran penjualan Pasardesa_id dalam 25 hari pertama operasi, yang dihasilkan dari 2.480 unit transaksi yang berhasil menjualkan 668 item produk yang berasal 54 unit mitra pasok yang ada di Desa Panggungharjo. Eksistensinya juga telah mendistribusikan $490 \mathrm{~kg}$ beras dalam 98 paket bantuan sembako hasil cash back dari pembeli.

Sehubungan dengan tulisan ini yang menelaah kapasitas aparatur pemerintah desa dalam upaya penanggulangan dan pencegahan penyebaran Corona Virus Disease 2019 (Covid-19) di wilayahnya mendasarkan pada 5 jenis kapasitas yang meliputi kapasitas responsif, kapasitas ekstraktif, kapasitas regulatif, kapasitas distributif dan kapasitas kolaboratif, maka dapat divisualisasikan esensi dari kapasitas-kapasitas yang dimaksud dalam table berikut.

Tabel 1. Kebutuhan Kapasitas Aparatur Pemerintah Desa Dalam Penanggulangan Dan Pencegahan Penyebaran Covid-19

\begin{tabular}{|c|c|c|}
\hline \multirow{2}{*}{$\begin{array}{c}\text { Elemen } \\
\text { Kapasitas }\end{array}$} & \multicolumn{2}{|c|}{ Hasil Analisa } \\
\hline & Aksi terhadap Kapasitas & Hasil \\
\hline Responsif & $\begin{array}{l}\text { - } \text { Musyawarah } \\
\text { - Membentuk satuan } \\
\text { tugas/pusat kendali beserta } \\
\text { organnya } \\
\text { - Membentuk sistem } \\
\text { komunikasi }\end{array}$ & $\begin{array}{l}\text { - } \text { Grand design penanganan dan } \\
\text { pencegahan di desa } \\
\text { - } \text { Ide inovasi dapat muncul } \\
\text { - Terdata riil kondisi warga terdampak } \\
\text { (klinis dan non klinissecara personal) } \\
\text { - Pengorganisasian terbentuk dan lebih } \\
\text { implementatif atas tugas dan fungsi }\end{array}$ \\
\hline Ekstraktif & $\begin{array}{l}\text { - Pembentukan relawan } \\
\text { - Pembagian peran dan } \\
\text { tanggung jawab } \\
\text { - Mengoptimalkan aset } \\
\text { desa (pasar desa) }\end{array}$ & $\begin{array}{l}\text { - } \text { Terpetakan actor pendukung diluar } \\
\text { pemerintah desa } \\
\text { - Peningkatan partisipasi } \\
\text { - Ide inovasi dapat muncul }\end{array}$ \\
\hline
\end{tabular}




\begin{tabular}{|c|c|c|}
\hline Regulatif & 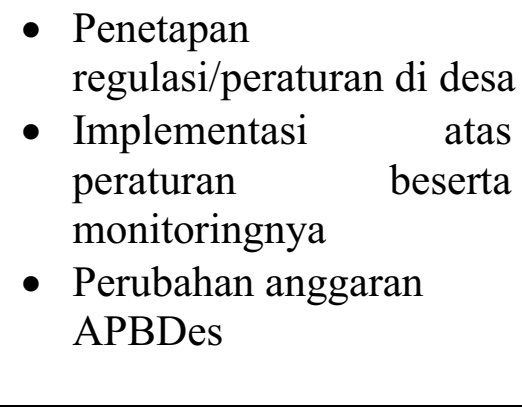 & $\begin{array}{l}\text { - Tingkat penyebaran wabah dapat } \\
\text { ditekan } \\
\text { - Pendayagunaan anggaran dapat } \\
\text { optimal } \\
\text { - Mitigasi secara k linis, sosial dan } \\
\text { ekonomi dapat optimal melalui } \\
\text { alokasi anggaran sesuai ketentuan } \\
\text { perundangan }\end{array}$ \\
\hline Distributif & $\begin{array}{l}\text { Distribusi logistic terhadap } \\
\text { warga terdampak klinis, non } \\
\text { klinis, sosial dan ekonomi }\end{array}$ & $\begin{array}{l}\text { Terjaminnya kecukupan pangan } \\
\text { (kebutuhan dasar) serta obat-obatan bagi } \\
\text { warga terdampak }\end{array}$ \\
\hline Kolaboratif & $\begin{array}{l}\text { Inovasi pada aset desa (pasar } \\
\text { desa melalui misalnya Pasar } \\
\text { desa berbasis online } \\
\text { (Pasardesa.go.id) }\end{array}$ & $\begin{array}{l}\text { - Kegiatan ekonomi berjalan dan } \\
\text { mempertahankan eksistensi } \\
\text { pendapatan warga di tengah } \\
\text { pandemic } \\
\text { - Kebutuhan pokok warga tercukupi }\end{array}$ \\
\hline
\end{tabular}

Sumber : diolah oleh penulis, 2020

\section{D.SIMPULAN}

Telaah mengenai kapasitas aparatur pemerintah desa yang diperlukan sebagai inovasi dalam upaya penanggulangan dan pencegahan penyebaran Corona Virus Disease 2019 (Covid-19) di wilayahnya dapat disimpulkan bahwa seorang kepala desa membutuhkan kapasitas responsif, kapasitas ekstraktif, kapasitas regulatif, kapasitas distributif dan kapasitas kolaboratif.

Kapasitas responsive akan mampu mendukung terbentuknya grand design penanganan dan pencegahan di desa, ide inovasi dapat muncul, terdata riil kondisi warga terdampak (klinis dan non klinis secara personal) dan pengorganisasian terbentuk dan lebih implementatif atas tugas dan fungsi. Kapasitas ekstraktif dan kolaboratif akan saling mendukung dan mendorong adanya informasi yang jelas actor pendukung diluar pemerintah desa, peningkatan partisipasi serta munculnya ide inovasi dengan mengoptimalkan teknologi informasi.

Kapasitas regulative akan mendukung mitigasi secara klinis, sosial dan ekonomi dapat optimal melalui alokasi anggaran sesuai ketentuan perundangan, pendayagunaan anggaran (dana di desa) dapat lebih optimal yang bermuara pada tingkat penyebaran wabah dapat ditekan. Kapasitas distributive dapat menjamin kecukupan pangan (kebutuhan dasar) serta obat-obatan bagi warga terdampak. Pada akhirnya kapasitas kolaboratif mendorong kegiatan ekonomi berjalan dan mempertahankan eksistensi pendapatan warga di tengah pandemic. Selain itu kebutuhan pokok warga tercukupi. Keseluruhan kapasitas tersebut dapat mewujudkan misi utama dari adanya wabah yaitu mitigasi, solidaritas, kolaborasi, dan ekonomi berbagi

\section{E. DAFTAR PUSTAKA}


WHO Director-general's Opening Remarks At the Media Briefing on Covid-19 - 11 March 2020 https://www.who.int/dg/speeches/detail/who-director-general-s-opening-remarks-at-themedia-briefing-on-Covid-19---11-march-2020.

WHO Coronavirus disease 2019 (COVID-19) Situation Report-80, Data as received by WHO from national authorities by 10:00 CET, 9 April $2020 \mathrm{https}: / / \mathrm{www}$. who.int/docs/defaultsource/coronaviruse/situation-reports/20200409-sitrep-80-Covid19.pdf?sfvrsn=1b685d64_4

GUGUS TUGAS PENANGANAN COVID-19 DIY,2020, Panduan Desa/Kelurahan/Kalurahan Tangguh Covid-19 Kumpulan Peraturan-Peraturan Mengenai Penanganan Covid-19 Di Desa, https://juraganberdesa.blogspot.com/2020/05/kumpulan-peraturan-peraturanmengenai-Penanganan-Covid-19-Desa.html

Kementerian Desa, Pembangunan Daerah Tertinggal dan Transmigrasi, 2020, Protokol Relawan Desa Melawan Covid-19.

Satgas COVID-19 UGM, 2020, buku saku Desa Tangguh COVID-19

Kementerian Kesehatan, 2020, Pedoman Pemberdayaan Masyarakat dalam Pencegahan COVID19 di RT/RW/Desa.

Kementerian Dalam Negeri, 2020, Pedoman Umum Kesiapsiagaan Menghadapi Penyakit Coronavirus (2019-nCoV) untuk Pemerintah Daerah

Undang-undang No. 36 Tahun 2009 tentang Kesehatan

Undang-undang No. 23 Tahun 2014 tentang Pemerintahan Daerah

Undang-undang No. 6 Tahun 2018 tentang Kekarantinaan Kesehatan

Peraturan Pemerintah Pengganti Undang-Undang Nomor 1 Tahun 2020, Kebijakan Keuangan Negara Dan Stabilitas Sistem Keuangan Untuk Penanganan Pandemi Corona Virus Disease 2019 (Covid-19) Dan/Atau Dalam Rangka Menghadapi Ancaman Yang Membahayakan Perekonomian Nasional Dan/Atau Stabilitas Sistem Keuangan

Peraturan Pemerintah Nomor 21 Tahun 2020 Pembatasan Sosial Berskala Besar Dalam Rangka Percepatan Penanganan Corona Virus Disease 2019 (Covid-19)

Keputusan Presiden Nomor 7 Tahun 2020, Gugus Tugas Percepatan Penanganan Corona Virus Disease 2019 (Covid-19).

Peraturan Menteri Kesehatan Republik Indonesia Nomor 9 Tahun 2020 Tentang Pedoman Pembatasan Sosial Berskala Besar Dalam Rangka Percepatan Penanganan Corona Virus Disease 2019 (Covid-19)

Surat Keputusan Kepala BNPB Nomor 9A Tahun 2020 tentang Penetapan Status Keadaan Tertentu Darurat Bencana Wabah Penyakit akibat Virus Corona

"Update Corona 9 April: Indonesia Tembus 3200 \& Dunia 1,5 Juta Kasus", https://tirto.id/eL7h

"Pasardesa.id "Berpacu Melawan Covid-19", http://www.panggungharjo.desa.id/ pasardesa-idberpacu-melawan-Covid-19/

Pasar Desa.id Desa Panggungharjo Raih Penjualan sebesar 100,69 juta. Sabtu Kliwon, 9 Mei 2020 05:07 WIB https://kec-sewon.bantulkab.go.id/berita/2020/05/pasar-desaid-desapanggungharjo-raih-penjualan-sebesar-10069-juta 